\title{
Food Industry in Egypt in the Late Roman Period (A.D 284-641)
}

\section{Mostafa El Rouby Gomaa}

Pharaohs High Institute for Tourism and Hotels

\begin{abstract}
:
In the late Roman era, the food industry such as bread, meat, salted fish, oil and wine, as well as other commodities, played an important role in public life, as it was mostly used for local production. The Egyptians innovated in variating their food industries, which were based on the satisfaction of buyers. the variety of the bread industry, which appeared in various forms is clearly recorded in Greek papyri uncovered from Greco-Roman Egypt. Food manufacturers have often followed Egyptian traditions inherited from ancient Egypt, yet they sometimes add new forms.

This article focuses on, the food industries in the late Roman or Byzantine period, especially in the countryside, as these industries are linked to their raw materials, which were concentrated in rural agricultural production or areas of consumption in cities.
\end{abstract}

Keywords: Food, Industry, Roman Egypt.

\section{Introduction:}

The state has been concerned with the provision of foodstuffs and commodities, especially food industry. It has forced traders to display part of their goods on the market and to announce a monthly price list. These traders were not intermediaries of food producers and manufacturers since manufactured food products were sold by their manufacturers (Bagnall, 2003).

The food industry was a local production industry, including bread, oil, and wine. The papyri are rich in mentioning many of these industries or mentioning them as a product to be paid in kind or as a commodity in the markets or as payments to the military forces (P. Oxy. 8.1115, 43.3115, and63. 4373)

\section{Bread industry}

The bread industry was one of the most important industries. The civic authority included the position of the eutheniarch, who was responsible, among other things, for supplying mills with of wheat on a daily basis. The process of grinding wheat normally comprised two phases: grinding and baking. In addition to the state mills, churches could also own a number of mills, not to

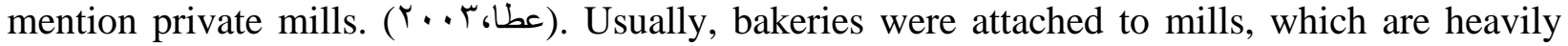
mentioned in Greek papyri (BGU.2. 405).

A papyrus dating back to A.D. 508 is a ten-month mill-lease contract between a woman named Serena, the owner of a mill, and two millers named Aurelius Apphouas and Olympian, a resident of Oxyrhynchus, who lease the mill with its equipment (P.Oxy.16.1890). Another contract dating back to AD 544 gives information about a specialist worker for cutting and preparing millstones to grind wheat and grain in mill for the house of Flavius Apion II (P.Oxy. 51.3641). A mill appears in a property list of a woman which dating back to the sixth century (Coptic Ostraca.15). Men and women equally worked in the food industry, where a papyrus dating back to AD 293 gives insights into the payment of the wages of bakers (miller Zulius and baker Pamon) (P.Oxy.17. 2143). Another document dating back to AD 348 records that a woman-owned mill and a bakery (BGU.2.405).In the fourth century, there was a male baker who makes white bread and cakes. (P.Oxy.8.1146).

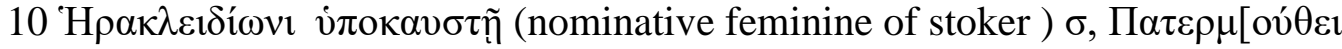

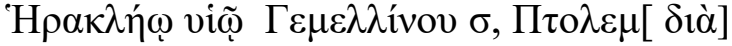

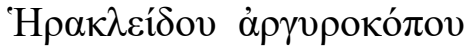


Women worked as bakers in public mills or at home, where most families have a hand mill at home to grind grain. There were also household ovens and many mills found in village houses and some monasteries. (Figure 1and 2)

In the late Roman era, bread was made from wheat, corn or barley (P.Oxy.43. 3115) but barley bread was less quality than wheat bread. It was more often found in poor households (Bagnall, 1996). Bread was sometimes made bread from corn.

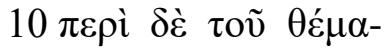

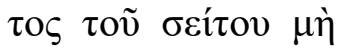

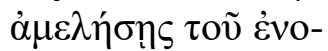

$\chi \lambda \tilde{\eta} \sigma \alpha \imath \Theta \omega v i ́ \omega$.

"With regard to the deposit of corn, do not neglect to worry Thonius". (P.Oxy.8.1159)

Bakeries made many bread forms, pies, and sweets ( $Y . .+r$ (عبد الحميد ومنصور). A papyrus dating back to the end of the third century gives information about the baker account and his creativity in the diversity of production. He stated that he produced large loaves, dried loaves, cakes, divided loaves and cookies (P.Oxy.14. 1655)

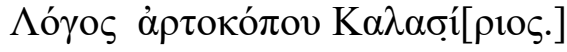

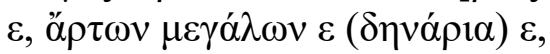

$\kappa \alpha \pi v \rho i ́ \omega v \zeta \varepsilon v \gamma \tilde{\omega} v \kappa(\delta \eta v \alpha ́ \rho i \alpha) \gamma$,

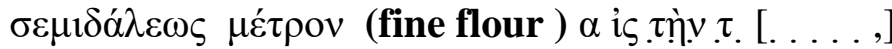

$5 \pi \lambda \alpha \kappa o v ́ v \tau \omega \nu(\delta \eta v \alpha ́ \rho ı) \gamma$.

$\zeta, \sigma \alpha 1 \mu 1 \delta \alpha ́ \lambda \varepsilon \omega \varsigma \mu \varepsilon ́ \tau \rho \circ \nu \alpha \kappa \alpha \lambda \varepsilon \omega \tau 1 \delta \varepsilon \varsigma[$. . ]

$\zeta, \mu \varepsilon \rho 1 \kappa \tilde{\omega} \nu \mu(\delta \eta v \alpha ́ \rho \imath \alpha) \imath \alpha(\delta \rho \alpha \chi \mu \alpha i) \beta$,

$\sigma \varepsilon \lambda 1 \gamma v i ́ \omega v \mu \varepsilon \gamma \alpha \dot{\lambda} \omega v \llbracket(\delta \eta v \alpha ́ \rho 1 \alpha) \rrbracket \mu(\delta \eta v \alpha ́ \rho 1 \alpha) \varepsilon(\delta \rho \alpha \chi \mu \alpha i) \gamma$,

$\sigma \varepsilon \lambda \imath \gamma v i ́ \omega v \mu 1 \kappa \tilde{\omega} v \zeta \varepsilon v ́ \gamma \eta \kappa(\delta \eta v \alpha ́ \rho 1 \alpha) \gamma$,

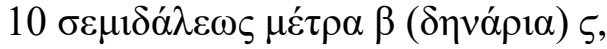

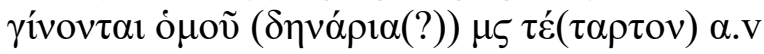

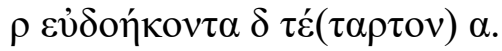

"Account of the baker Kalasiris. The 5th, 5 larg loaves 5 denarii, 20 pairs of dried loaves 3 den., I measure of the fine flour, cakes 3 den. The 6th, I measure of fine flour... The 7th, 40 divisible loaves, 11 den. 2 dr., 40 large cakes 5 den. dr., 20 pairs of small cakes 3 den., 2 measures of fine flour 6 den., total 46 den.

Another document dating back to the fourth century was a request to send a bowl of honey to prepare pies for the feast (P. Oxy.48. 3406).

The wheat was varieties. The high-quality wheat used in white bread and cakes (P. Oxy.8.1146). It was baked from the previous year crops and appeared in the calculations of the rich houses and celebration supply (P. Oxy.7.1071). while there were other kinds of bread as was mentioned, there was wheat mixed with corn or it was cheap wheat, which was mentioned in a document dating back to the third century (SB.16. 12607)

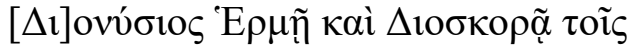

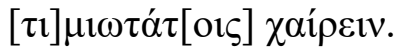

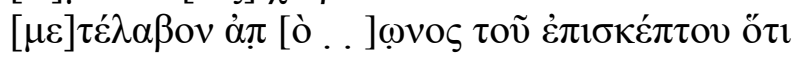

oi $\pi \mathrm{o} \lambda \lambda$ oì $\tau \tilde{\omega} v \grave{\alpha}[\pi \alpha i \tau] \mathrm{ov \mu \varepsilon ́v \omega v} \mathrm{ov̉ \kappa} \mathrm{à \pi o \kappa \rho \varepsilon í-}$

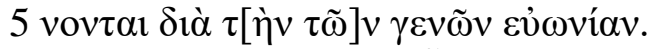

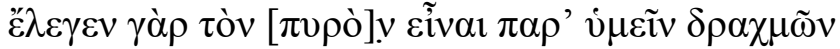

"Dionysius to the most esteemed Hermes and Dioskorus, greeting. I knew from the inspector ... that the majority of those who are being dunned for taxes do not respond because of the 
cheapness of the crops. For he was saying that wheat is going in your locality for twelve drachmas."

\section{Meat}

There was much animal-protein food. It was different from poor to rich families, or from one kind to another. There was spread of livestock, sheep, goats, and dairy products. In addition to poultry, eggs, and fish.

Beef was rarely mentioned in documents where a papyrus dating back to the end of the third century recorded it (SB.14. 12156). Veal (buffalos' meat) was mentioned in many documents. It seems because of geographic reasons, as buffaloes live in hot areas beside rivers on farming land. (SB.6.9563, and P.Oxy. 54. 3765).

Sheep and goats were very widespread. The main purpose of them was collecting wool (Toutain;1930). But there was no doubt that they were a primary source of meat. In addition to camels were also a source of meat, although they rarely mentioned in the documents except in the case of transportation and travel activities. An Ostraca dating back to the end of the sixth century mentioned it to load a grain only (Coptic Ostraca. 230)

Pork (pig meat) was manufactured and more widespread because it is easy to store it in two ways: first it was fermented as a slice of pickled pork (preserved ub diluted wine) (SB.16. 12663).

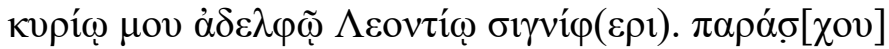

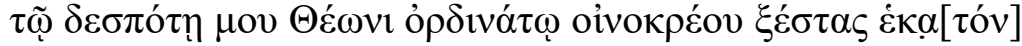

"My dear brother, Leontius, provide my honorable Theon one hundred of pickled pork."

The second, it was a slice of Salted pork (P. Ryl.4. 693,695, and 696). It was mentioned in the documents for military forces supply. The pork was one of the favorite meats for the military forces. It was distributed to military forces as a military supply (P.Oxy.16. 2013)

\section{Cheese}

Milk was one of the sources of animal-protein. It went into the food industry such as dairy products. A papyrus dating back to the fourth century mentioned two jars of cheese (P. Oxy.14. 1776)

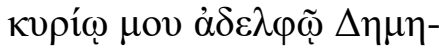

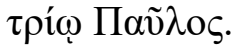

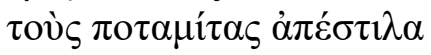

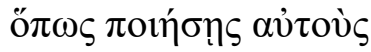

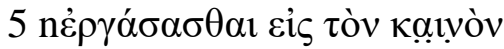

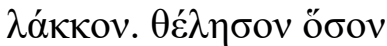

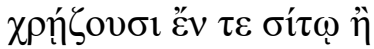

ỏ

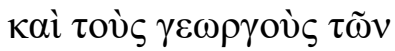

$10 \tau \rho \imath \tilde{\omega} \nu \mu \eta \chi \alpha \nu \tilde{\omega} \nu \tau o \tilde{v}$

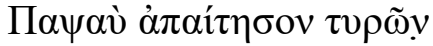

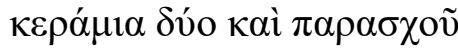

$\alpha \hat{\tau} \tau \tilde{i} \zeta$.

In this document a letter from Paulus to Demetrius, telling him that; some river-workmen were being sent for a piece of work, and that they were to be supplied with corn, wine, and cheese. Another papyrus dating back to the fourth or fifth century mentioned three hundred flat cheese sale after making it. (P. Ant.2.92) 


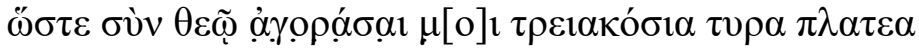

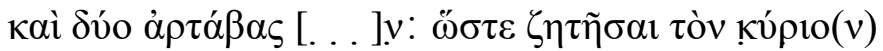

"Be on the lookout for three hundred flat cheese and two artisans ... ] to ask for the sermon (s)". Although there had been papyrus dairy products, their manufacture and consumption had mainly been domestic.

\section{The salted fish}

Fish was a popular meal among Egyptians. It had been mentioned extensively in documents, either in meals or in preparing for celebrations. In the Roman era, A papyrus dating back to AD 100 gives insights into celebrating a birthday with fish (P. Fay. 114). In the Later Roman and Byzantine era, the same thing persisted, where a papyrus gives information about a letter was sent from Menas to Theodour, the agent of Abion, with a gift of fish on the occasion of the

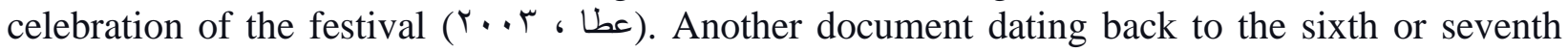
century showed the salted fish as a gift on the feast of the Epiphany. (P.Oxy.16. 1857)

Fish sellers were often wives of fishermen. Men caught fish during the day, and women sold fish in the city in the evening and then became sold at any time (Lindsay; 1965). A papyrus dating back to AD 569 mentioned fish sellers. (P. Cairo Mas.1. 67023). However, the salted fish was mentioned more in the documents. It was kinds where it pickled and brewed (Pickled mullet) in a broth called Garum (P. Oxy.10. 1299, and 34.2728).

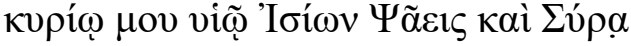

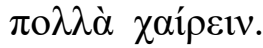

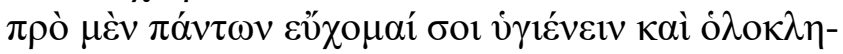

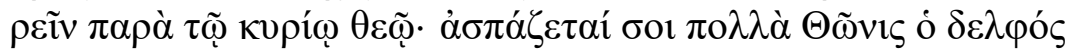

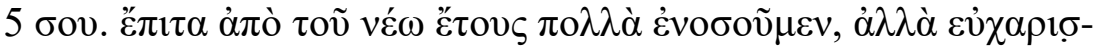

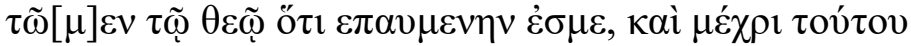

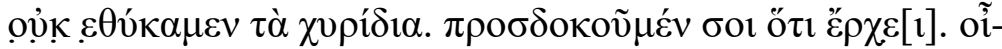

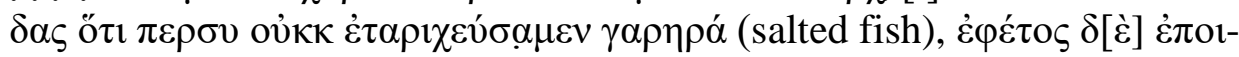

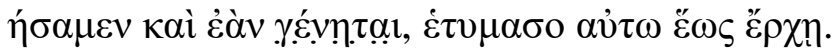

"To my lord and son Ison from Psais and Syra, many greetings. Before all else I pray to the lord God for your health and prosperity; Thonis your brother sends you many salutations. Next, since the new year I have been very ill, but we give thanks to God that I have recovered ; and up to the present time we have not sacrificed the pigs. We are expecting you to come. You know that on your account we have not salted any fish, but we have made the pickled yearly, and, if possible, I will prepare it for your coming".

It had brewed in kinds of sauce. There was a Guild of the fish-sauce and mentioned in some documents. A papyrus dating back to AD 319 showed the guild of the fish-sauce sellers. (P. Oxy.54. 3749).

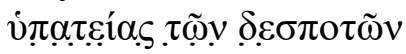

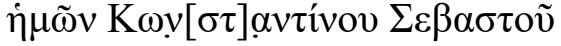

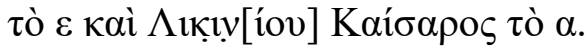

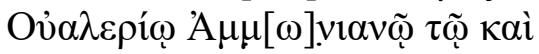

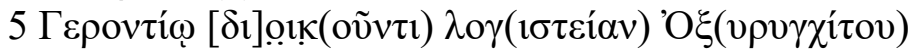

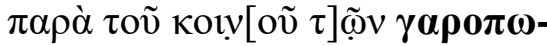

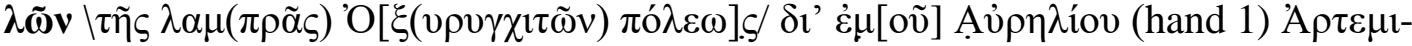

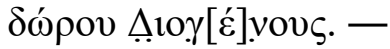

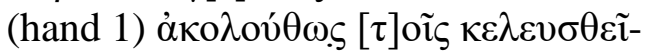

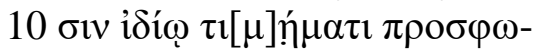


$\nu \tilde{\omega} \tau \eta े . ~[\dot{\varepsilon} \xi \tilde{\eta} \varsigma \dot{\varepsilon}] v \gamma \varepsilon \gamma \rho \alpha \mu \mu \dot{\varepsilon} v \eta(v)$

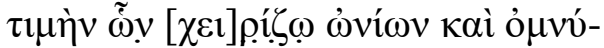

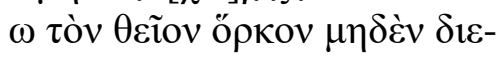

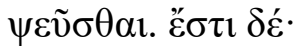

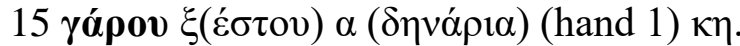

"To Valerius Ammonianus alias Gerontius, administering the office of curator of the Oxyrhynchite, from the guild of the fish-sauce sellers of the Oxy., through me Aurelius (h 1) "Artemidorus, son of Diogen, I declare the price entered below for the goods which I handle..."

The guild of the fish-sauce was mentioning until the end of the Byzantine age in Egypt (P. Amh. 2.154)

\section{Oils}

Oils were both ancient and modern in the Middle East and particularly in Egypt, an essential addition to meals. It was added on legumes to make it palatable, added on bread and used in cooking meat. It had calories less than animal fat. Especially, oils in Byzantine Egypt made from plants (Bagnall: 1996).

The oil was mentioned in the papyri many times without specifying its kind of it. Especially, when tacked about monasteries which they had oil presses and worked by monks (Coptic Ostraca. 78). Or oil workers (P. Oxy.20. 2273,51. 3641, and 4340).

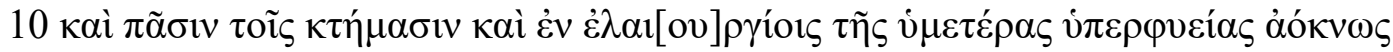

"as well as the estate and the oil workers of the present day"

Kind of oil was mentioned in the documents which tacked about oil sellers. A papyrus dating back to AD 275 recorded that a declaration from the seller of fine oil (olive oil) and what he had oil (P. Oxy.12. 1455)

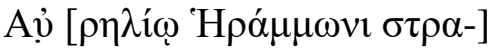

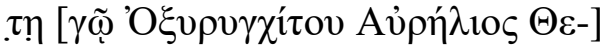

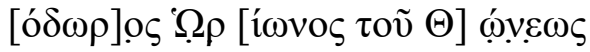

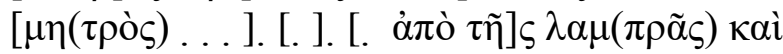

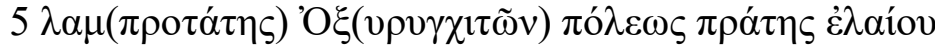

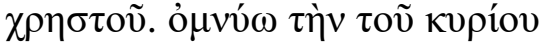

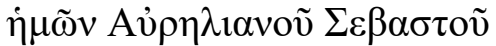

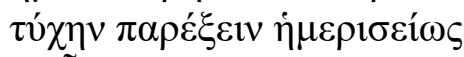

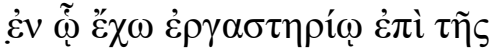

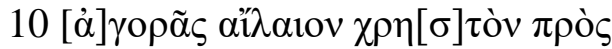

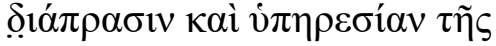

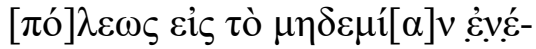

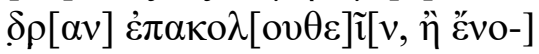

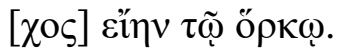

"To Aurelius strategus of the Oxyrhynchite nome, from Aurelus Theodoras son of Horion son of Thonis, his mother being . .., of the illustrious and most illustrious city of Oxyrhynchus, seller of fine oil. I swear by the fortune of our lord Aurelianus Augustus that I will provide daily in the factory which I possess in the market-place fine oil for sale and service of the city."

Another document dating back to $320 \mathrm{AD}$, an oil saleswoman from Panoplies, Aurelia Theodora, leases the third floor of a house owned by him (Bagnall: 1996). They must declare their stock and prices monthly in the Guild of oil sellers. (1999، (199). 
In the Roman and Byzantine era in Egypt, oils extracted from the seeds of some grains or vegetables. For example, a papyrus dating back to $\mathrm{AD} 234$ with an agreement with a dancer to dancing in a ceremony, including the payment of two Amount of radish oil (P. Oxy.34. 2721).

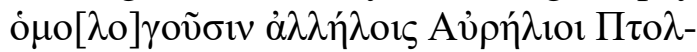

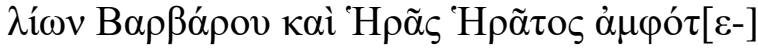

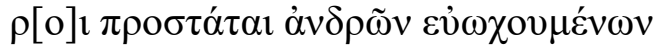

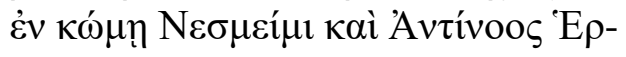

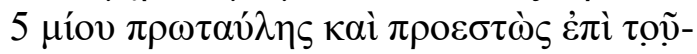

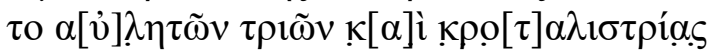

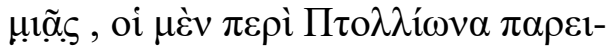

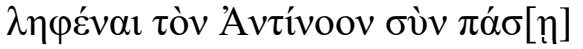

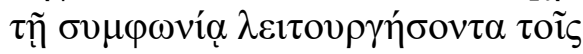

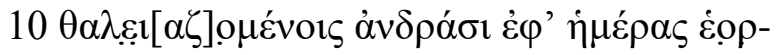

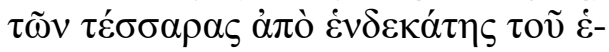

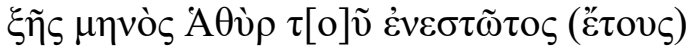

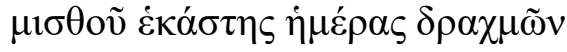

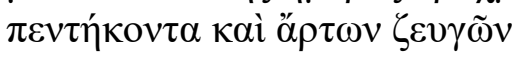

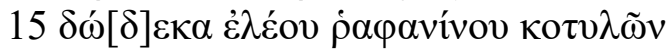

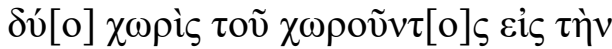

$\lambda \alpha \mu \pi \alpha \dot{\alpha} \alpha$

"Contract with Aurelius Ptollion, son of Barbarus, and Aurelius Heras, Son of Heras, both presidents of the men of the village of Nesmeimis, who are celebrating a festival, and Antinous, son of Hermias, first flute and supervisor for this occasion, of three flute-players and one castanet dancer, Ptollion's party that they have taken on Antinous and the whole band to do service for the men who are having a feast for four days of festival from the eleventh of the next month of Hathyr of the present year, at a daily rate of fifty drachmae, twelve pairs of loaves, two Amount of radish-oil ....."

Flaxseed was also used in the manufacture of oils (199V، محمد). Another document dating back to the end of the third century mentioned the olive and sesame oil in a list of articles for a sacrifice. (P. Oxy.36. 2797).

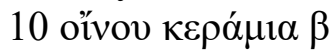

$\mu \dot{\lambda} \lambda 1, \gamma \alpha \dot{\lambda} \lambda \alpha$, č̀ $\lambda \alpha 10 v$,

$\sigma \eta \sigma[\alpha(\mu 1 v o v) \ddot{\varepsilon}] \lambda \alpha \_v$,

10 wine ceramics $b$

honey, milk, olive oil, sesame oil,

The seeds of lettuce, cabbage, safflower, linseed, behen nuts and sesame contain oil used in cooking or lighting which were planted to produce oils (Bagnall: 1996, and Marijke, 1999). Olive was a well-known plant for making oil in Egypt. It used as a food in ancient Egypt, but with the advent of the Greeks to Egypt, it was the most used in food. (r..r، عبد الحميد ، ومنصور (r). It was called fine, Good, or sweet oil to discern from Other lesser quality oils, especially radish oil, were used by monks as a sign of asceticism and in Lighting.

It seems increasingly clear that it was possible to transport olive oil by land across vast stretches of desert (Fayoum and oasis) and still have them competitive in Egyptian markets (Bagnall, 2005)

\section{Figures}




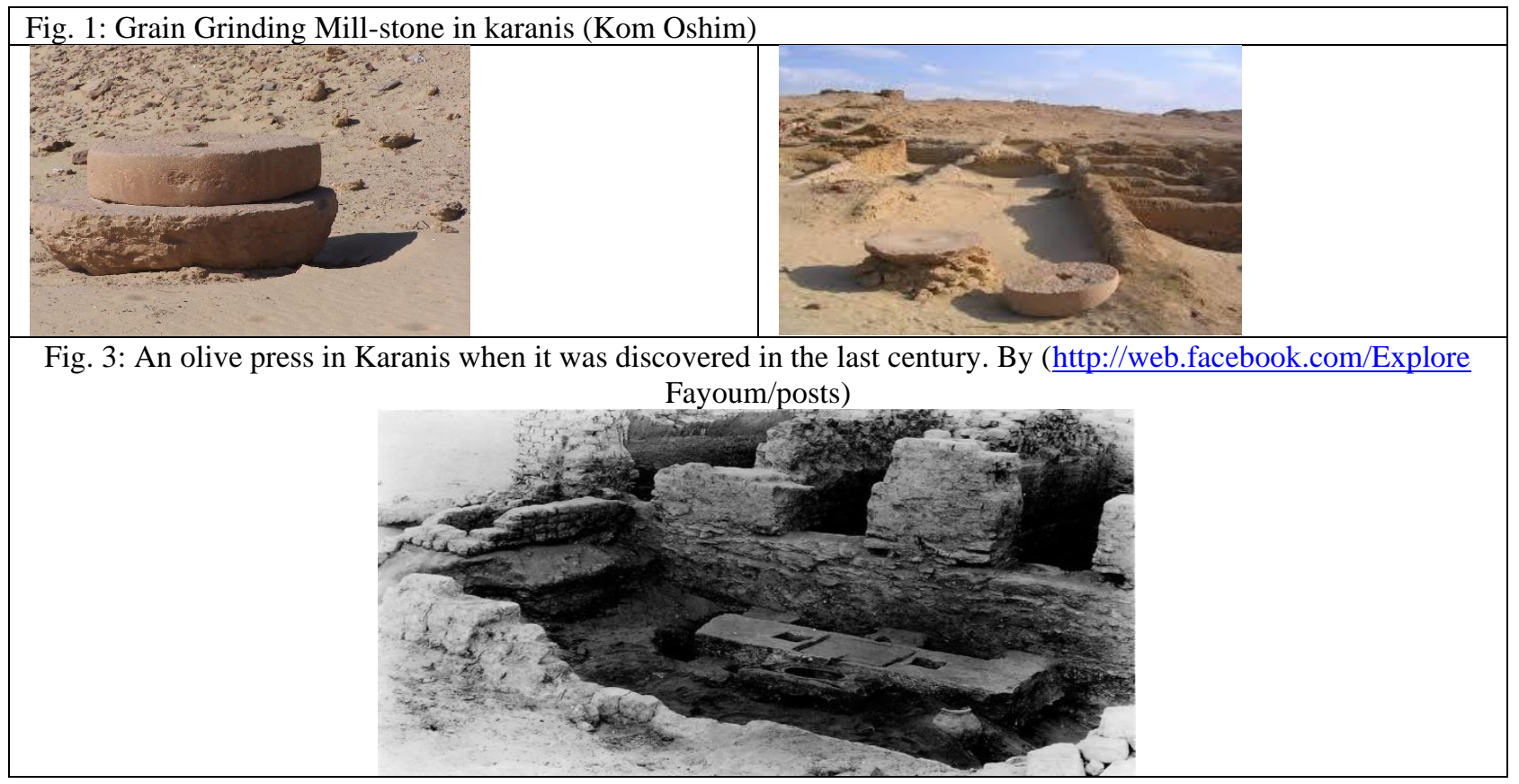

\section{References}

B.G.U= Aegyptische Urkunden aus den Konig Lichen, Museum Zu Berlin, I-XVIII, 1895 2000 .

Coptic Ostraca $=$ Crum, W.E, (1902). Coptic Ostraca, From the collection of the Egyptian exploration fund, the Cairo Museum and others, London.

P.Amh $=$ The Amherst papyri of Lord Amherst of Hackeny by B.b. Grenfell \& A.S. Hunt, 2 Vols London 1900 - 1991.

P.Ant= The Antinoopolis Papyri, ed J.W.B. Brans \& C.H. Roberts in 3 Vols.

P. Cairo. Masp = Catalogue General Antiquities Egyptiennes, papyrus Grecs d'epoque Byzantine, ed M. J. Maspero. Le Caire, 1911.

P.Fay= Fayum Towns and their papyri, ed B.P. Grenfell \& A.S. Hunt and D.g. Hogart, London, 1900.

P. Oxy= Oxyrhnchus papyri, ed B.p, Grenfell \& A.S. Hunt and others, 67 vols, 1998-2001

$\mathrm{SB}=$ Sammelbuch griechischer Urkonden aus Ägypten, 21 vols, Berlin, 1915- 1998.

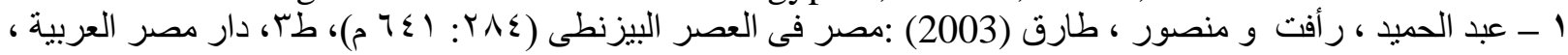

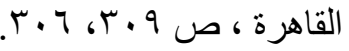

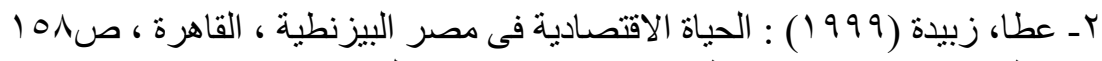

Bagnall, R.S. (1996). Egypt in late Antiquity, Princeton, 4 th printing.

Bagnall, R.S. (2003). Price in Sales on delivery in later Roman Egypt, Ashgate.

Bagnall, R. S. (2005). Evidence and Modals for the Economic of Roman Egypt, Stanford, p197.

Hardy E. (1931). The Large Estate of Byzantine Egypt, New York.

Johnson A. Ch. and West L.C. (1949). Byzantine Egypt, Economic Studies, Princeton.

Lindsay J. (1965). Daily Life in Roman Egypt, London.

Marijke, V. (1999). The Food and Fodder Supply to Roman Quarry Settlements in the Eastern Desert of Egypt; In The Exploration of plant Resources in Ancient Africa. Susan E. Alcock, Robin Osborne, 171-183.

Toutain, J. (1930). The Economic Life of the ancient world, London. 
International Journal of Heritage, Tourism and Hospitality Vol. (14), No. (3) Spsecial Issue

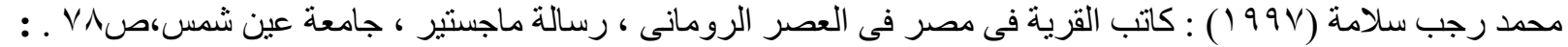
http://trip-suggest.com/egypt/al-fayyum/furqus/

http://web.facebook.com/Explore Fayoum/p 